DOI: 10.20472/IAC.2018.037.002

\author{
KATARZYNA BANASIK \\ Andrzej Frycz Modrzewski Krakow University, Poland
}

\title{
EXPUNCTION OF CONVICTION FOR FISCAL CRIMINAL OFFENCES IN POLAND
}

\begin{abstract}
:
The subject of the article is the expunction of conviction for fiscal criminal offences and misdemeanours under Polish criminal law. The author starts her article by emphasising the social and legal importance of the expunction of conviction and explains the essence of the institution. She then goes on to present the Fiscal Criminal Code as an independent legal act and elaborates on its connections to the Criminal Code. In the main part of the article, the author analyses the legal basis for the expunction of conviction for fiscal criminal offences and presents an in-depth analysis of the regulations governing the expunction of conviction for fiscal criminal offences. She goes on to examine the issue of absolution of a conviction for fiscal criminal offences and misdemeanours through a Presidential pardon. As a result of the analysis, the author makes assessment of the present state of the law as to the expunction of conviction for fiscal criminal offences and misdemeanours. The author suggests that it is necessary to amend some of the existing regulations and proposes a number of de lege ferenda postulates.
\end{abstract}

\section{Keywords:}

fiscal criminal offences, fiscal criminal code, expunction of conviction, periods of expunction of conviction, fixed penalty notice, pardon

JEL Classification: K00, K14, K14 


\section{Introduction}

The institution of expunction of conviction, including expunction of conviction for fiscal criminal offences, has a great legal and social significance. Under fiscal criminal law, any prior convictions for intentional fiscal criminal offences constitute the ground for re-offending, which implies the obligatory application of more severe penalties (Art. $37(1)(4)$ of the Fiscal Criminal Code ${ }^{1}$ ). Any prior judgement of conviction may be considered only until the moment of the expunction of conviction. Expunction of conviction has significant social consequences. A conviction will stigmatise the offender and often isolate them from the rest of society. Moreover, certain occupations, functions and offices legally require that candidates have a clear criminal record, including a record free from any convictions for fiscal criminal offences ${ }^{2}$.

The expunction of conviction is a process by which a conviction is removed from a person's records and is considered to have never occurred (Art. 106 of the Criminal $\mathrm{Code}^{3}$ ). As a standard, the Polish doctrine assumes that the expunction of conviction creates a legal fiction whereby a former convict is treated as if they have never been convicted. The scope of expunction is, however, still subject to dispute. Some experts claim that following expunction it is assumed that neither the conviction nor the committal of an offence took place. Another stance is that expunction of conviction does not cover the related criminal offence. Courts' decisions concerning this issue seem to be quite consistent in this respect. Namely, there is a predominant stance which claims that "Expunction of conviction results in a situation where both conviction and the committal of an offence are treated as if they have never occurred. This creates a legal fiction that the offence has never been committed. Since the moment criminal records are expunged it is - from the perspective of the legal order - founded to say that a given criminal offence has not taken place at all" (ruling of the Supreme Court of 18 June 2009) 4 . In this author's opinion, upon expunction the entirety of a conviction, i.e. both the conviction itself and the relevant criminal act underlying it, should be treated as if they have never occurred. The essence of expunction involves some sort of "legal oblivion" where it is "forgotten" that a person was convicted of a crime. The essence of expunction of conviction consists in the recognition that a conviction has not occurred, i.e. in the treatment of the person whose criminal records have been removed is treated as if they have never been involved in a crime,

\footnotetext{
${ }^{1}$ Statute of 10 September 1999 - The Fiscal Criminal Code, Official Journal "Dziennik Ustaw” No. 83 item 930 , as amended.

${ }^{2}$ More on this topic see: K. Banasik, Ustawowy wymóg niekaralności [in:] K. Banasik (ed.), A. Kargol (ed.), M. Lubelski (ed.), E. Plebanek (ed.), A. Strzelec (ed.), W poszukiwaniu prawdy. Rozważania o prawie, historii $i$ sprawiedliwości, Kraków 2018, pp. 25-34.

${ }^{3}$ Statute of 6 June 1997 - The Criminal Code, Official Journal "Dziennik Ustaw" No. 88 item 553, as amended.

4 The ruling of the Supreme Court of 18 June 2009, IV KK 164/09, LEX no. 512114. The Supreme Court decided nearly identically in the ruling of 9 December 2009 (V KK 303/09, LEX no. 553740), in the ruling of 10 November 2010 (IV KK 326/10, „Prokuratura i Prawo” - „Orzecznictwo” 2011, no. 3, item 8) and in the ruling of 29 August 2013 (IV KK 168/13, http://www.sn.pl/sites/orzecznictwo/orzeczenia3/iv\%20kk\%20168-13.pdf, accessed: 25.02.2017).
} 
suspected of or charged with it, and as if they have never been sentenced or punished for it ${ }^{5}$.

\section{The Fiscal Criminal Code as an autonomous legal regulation}

To begin with, the problem of taxonomy of prohibited acts should be tackled. Under Polish law, acts forbidden under penalty can be divided into criminal offences and misdemeanours. Criminal offences can be further divided into common criminal offences (referred to simply as "criminal offences") and fiscal criminal offences (always qualified by the adjective "fiscal"). Common criminal offences are defined in the Criminal Code and many statutory acts that regulate the various areas of life. Fiscal criminal offences are defined solely in the Fiscal Criminal Code ${ }^{6}$. The situation is similar in the case of misdemeanours: they are classified as common misdemeanours (referred to simply as "misdemeanours") and fiscal misdemeanours (always qualified by the adjective "fiscal"). Common misdemeanours are defined in the Misdemeanours Code and many statutory acts that regulate the various areas of life. All fiscal misdemeanours are defined in the Fiscal Criminal Code.

Fiscal criminal law combines the disciplines of criminal law and financial law ${ }^{7}$. It is a field of criminal law in the broader sense, distinct from common criminal law. Fiscal criminal law is an area of criminal law which specialises in the protection of specific interests, namely financial interests of the State Treasury, local government units and the European Union ${ }^{8}$. The main source of fiscal criminal law is the Fiscal Criminal Code. However, when defining prohibited acts in the Fiscal Criminal Code, the legislator used the construct of a blanket provision ${ }^{9}$. The regulations included in the specific part of the Code, defining fiscal criminal offences and misdemeanours, do not allow for the contents of a given criminal offence or misdemeanour to be determined. They require a further reference to provisions of financial law, i.e. provisions concerning tax matters, customs, foreign currency and gambling.

The Fiscal Criminal Code is an autonomous legal regulation ${ }^{10}$, standing independently from the Criminal Code and Misdemeanours Code. As a rule, fiscal criminal offences are not covered by provisions included in the general part and Chapter XXXVIII (General provisions concerning soldiers) of the Criminal Code (Art. 20(1) of the Fiscal Criminal Code). Art. 20(2) of the Fiscal Criminal Code points to exceptions, i.e. provisions of the Criminal Code, which are nevertheless applied accordingly to fiscal

\footnotetext{
5 More on the essence of the expunction of conviction see: K. Banasik, Istota zatarcia skazania, "Wojskowy Przegląd Prawniczy" 2017, no. 2, pp. 36-49.

${ }^{6}$ Similarly L. Gardocki, Prawo karne, Warszawa 2013, p. 2; A. Marek, Prawo karne, Warszawa 2011, p. 11.

${ }^{7}$ M. Błaszczyk [in:] M. Błaszczyk, M. Zbrojewska, Kodeks karny skarbowy, Warszawa 2011, p. 7.

${ }^{8}$ M. Błaszczyk [in:] M. Błaszczyk, M. Zbrojewska, op. cit., pp. 7-8.

${ }^{9}$ M. Błaszczyk [in:] M. Błaszczyk, M. Zbrojewska, op. cit., p. 6.

10 Similarly T. Grzegorczyk, Kodeks karny skarbowy. Komentarz, Warszawa 2006, p. 163 and p. 236; A. Marek, Prawo karne, op. cit., p. 11.
} 
criminal offences. They include expunction of conviction provisions. Thus, only some of the Criminal Code provisions have been assimilated into the Fiscal Criminal Code. In accordance with Art. 46 of the Fiscal Criminal Code, fiscal misdemeanours are not covered by the general part of the Misdemeanours Code. Thus, substantive law issues related to fiscal misdemeanours are regulated in the Fiscal Criminal Code fully autonomously and independently from the Misdemeanours Code ${ }^{11}$. Fiscal criminal law regulates expunction of conviction for fiscal misdemeanours on its own, in Art. 52.

The regulations of the Criminal Code concerning expunction of conviction are thus applied accordingly to fiscal criminal offences ("accordingly" as opposed to "directly"). Provisions of the Criminal Code should be applied in a way that takes into account the specific character of the Fiscal Criminal Code ${ }^{12}$. In other words, the provisions of the Criminal Code should be applied in a manner that is consistent - in terms of content with the regulations of fiscal criminal law that can't be eliminated by the assimilated provisions $^{13}$.

\section{Expunction of conviction for fiscal criminal offences}

A fiscal criminal offence is defined in Art. 53(2) of the Fiscal Criminal Code. As per the above article, a fiscal criminal offence is an act forbidden under the penalty of dayfines, restriction of personal liberty or imprisonment. The types of sentences that can be imposed for fiscal criminal offences are mentioned in Art. 22(1) of the Fiscal Criminal Code. They include: 1) a day-fine; 2) restriction of personal liberty; 3) imprisonment.

The rules for imposing the penalty of fine are mentioned in Art. 23 of the Fiscal Criminal Code as follows: 1 . When imposing the penalty of fine, the court shall specify the number of daily units and the amount of one daily unit; if not specified otherwise in the Code, the lowest number of units is 10 , while the highest is 720 . 2. The court may issue a fine order for up to 200 daily units, unless the Code provides for a less severe penalty. 3 . When determining the amount of a daily unit, the court takes into account the perpetrator's income, their personal and familial situation, financial standing and their ability to earn; the daily unit may not be lower than one thirtieth of the minimum wage or exceed the value of the minimum wage by more than four hundred times.

The severity of the restriction of personal liberty is determined accordingly on the basis of, for example, Art. 34 of the Criminal Code, which means that the minimum penalty is at least one month and the maximum penalty is 2 years (unless the act

\footnotetext{
11 Similarly V. Konarska-Wrzosek [in:] V. Konarska-Wrzosek, T. Oczkowski, J. Skorupka, Prawo i postępowanie karne skarbowe, Warszawa 2013, p. 37.

12 A. Wielgolewska [in:] A. Wielgolewska, A. Piaseczny, Kodeks karny skarbowy. Komentarz, Warszawa 2012 , p. 69; G. Łabuda [in:] P. Kardas, G. Łabuda, T. Razowski, Kodeks karny skarbowy. Komentarz, Warszawa 2017, p. 358.

${ }^{13}$ So L. Wilk [in:] L. Wilk, J. Zagrodnik, Kodeks karny skarbowy. Komentarz, Warszawa 2016, p. 116.
} 
provides otherwise). The sentence may be imposed to last months or years. The restriction of personal liberty sentence involves: the obligation to provide unpaid, controlled community work; deduction of $10 \%-20 \%$ of monthly salary for a social cause indicated by the court. The above obligation and deduction are decreed jointly or separately. During the term of restriction of personal liberty, a convicted person: may not change their place of residence without the court's approval; is obliged to provide clarifications on the course of their sentence.

The severity of an imprisonment sentence for fiscal criminal offences is defined in Art. 27 of the Fiscal Criminal Code as follows: 1. Unless provided otherwise in the Code, the sentence of imprisonment may be imposed for a period as short as 5 days or, as long as, 5 years; it is imposed in days, months, or years. 2. The sentence of military detention may be imposed for a period as short as 5 days or, as long as, 2 years; it is imposed in days, months, or years.

Pursuant to Art. 22(2) of the Fiscal Criminal Code punitive measures used in fiscal criminal offences include: 1) voluntary submission to liability; 2) forfeiture of objects; 3 ) collection of a monetary equivalent to forfeiture of objects; 4) forfeiture of financial gain; 4a) collection of a monetary equivalent to forfeiture of financial gain; 5) ban on involvement in a certain business activity, profession or position; 6) public announcement of a sentence; 7) deprivation of public rights; 8) measures connected with putting the perpetrator on probation: a) conditional discontinuation of criminal proceedings, b) conditional suspension of execution of a sentence, c) conditional release.

In Art. 22(3) the Fiscal Criminal Code provides for the following protective measures: 1) electronic monitoring of offenders; 2) therapy; 3) therapy for addictions; 4) commitment to a psychiatric hospital; 5) forfeiture of objects; 6) ban on involvement in a certain business activity, profession or position.

Expunction of conviction for fiscal criminal offences is subject to, accordingly, Art. 106, Art. 107 and Art. 108 of the Criminal Code. The already-mentioned Art. 106 of the Criminal Code defines what the expunction involves. Pursuant to the provision, upon its expunction a conviction is treated as having never occurred and a relevant criminal record is removed from the register of convicts, i.e. the National Criminal Register. The National Criminal Register includes data about people who have been convicted by a valid judgement for fiscal criminal offences (Art. 1(2)(1) of the National Criminal Register Act ${ }^{14}$ ). Art. 107 of the Criminal Code defines the terms of expunction of conviction. Applying this provision accordingly to fiscal criminal offences, an imprisonment sentence is expunged, by operation of law, 10 years after the enforcement of a penalty, absolution or expiration of the deadline for enforcement. Following a petition by the convict, the court may order expunction of conviction after 5

\footnotetext{
14 Statute of 24 May 2000 on the National Criminal Register, Official Journal "Dziennik Ustaw" No. 50 item 580 , as amended.
} 
years, provided the convict has obeyed the law in this period and the imprisonment sentence did not exceed 3 years. The restriction of personal liberty sentence is expunged, by operation of law, 3 years after the enforcement of a penalty, absolution or expiration of the deadline for enforcement. The fine penalty for a fiscal criminal offence is expunged, by operation of law, 1 year after the enforcement of a penalty, absolution or expiration of the deadline for enforcement. In the case of penalties such as restriction of personal liberty and fine, the Fiscal Criminal Code does not provide for an earlier expunction of conviction, i.e. expunction following a convicted person's petition.

The issue of expunction of conviction also arises when the court waives a penalty. The Fiscal Criminal Code regulates penalty waivers in Art. 19. When this institution is applied, a judgement of conviction is passed ${ }^{15}$ and an accused person is deemed to have been convicted, but not punished. In the case of a penalty waiver, the expunction of conviction of a fiscal criminal offence happens by operation of law after a year from passing of the final judgement (Art. 20(2) of the Fiscal Criminal Code in conjunction with Art. 107(5) of the Criminal Code).

The issue of expunction of conviction in the case of punitive measure decrees is regulated in Art. 45(2) of the Fiscal Criminal Code as follows: Expunction of the punitive measures mentioned in Art. 22(2)(2)-(7) is subject, accordingly, to Art. 107(6) of the Criminal Code. Thus, if a punitive measure in the narrow sense was decreed, expunction of conviction may not happen before the enforcement, absolution or expiration of the deadline for enforcement. The above provision stipulates that expunction may not be applied to the punitive measure mentioned in Art. 22(2)(1), i.e. to voluntary submission to liability. A judgement that allows voluntary submission to liability does not constitute a judgement of conviction ${ }^{16}$. In this case, a fiscal offender is not deemed to have the status of a convicted person ${ }^{17}$. In accordance with Art. 18(2) of the Fiscal Criminal Code, a final and enforceable judgement allowing voluntary submission to liability is not registered in the National Criminal Register. As a consequence, expunction of conviction does not apply to voluntary submission of liability.

The "absolution" mentioned in the above provisions may be granted under an amnesty or a pardon ${ }^{18}$. In accordance with Art. 139 of the Constitution ${ }^{19}$, the right of pardon is

\footnotetext{
${ }^{15}$ Compare L. Gardocki, op. cit., p. 188; W. Wróbel, A. Zoll, Polskie prawo karne. Cześć ogólna, Kraków 2013, p. 543; A. Marek, Kodeks karny. Komentarz, Warszawa 2010, p. 207.

${ }^{16}$ Compare F. Prusak, Kodeks karny skarbowy. Komentarz. Tom I. Komentarz do art. 1-53 k.k.s., Kraków 2006, p. 297.

17 Compare L. Wilk [in:] L. Wilk, J. Zagrodnik, op. cit., p. 105.

${ }^{18}$ A. Grześkowiak [in:] A. Grześkowiak (ed.), K. Wiak (ed.), Kodeks karny. Komentarz, Warszawa 2015, p. 684; M. Błaszczyk [in:] M. Królikowski (ed.), R. Zawłocki (ed.), Kodeks karny. Część ogólna. Tom II. Komentarz do art. 32 116, Warszawa 2015, p. 685; N. Kłączyńska [in:] J. Giezek (ed.), Kodeks karny. Część ogólna. Komentarz, Warszawa 2012, p. 651; G. Bogdan [in:] A. Zoll (ed.), Kodeks karny. Część ogólna. Komentarz, t. l: Komentarz do art. 1-116 k.k., Warszawa 2007, p. 1116.
} 
exercised by the President of the Republic of Poland. The use of this right is part of the so-called Presidential Prerogatives ${ }^{20}$, which means that in order to be valid, the pardon does not have to be officially approved by the Prime Minister (Art. 144 of the Constitution). The right of pardon has not been defined in any act. The only statutory restriction concerning the right of pardon can be found in Art. 139 of the Constitution, which says that the right cannot be used with respect to people convicted by the State Tribunal. It is widely accepted in the doctrine that the President has very wide competences when it comes to pardon ${ }^{21}$. They may, for example, diminish the penalty imposed or absolve a person of a penalty in its entirety ${ }^{22}$. The right of pardon may also involve an earlier expunction of a conviction ${ }^{23}$. It does not, however, apply to protective measures ${ }^{24}$. In the literature, it is rightly assumed that by exercising the right of pardon, the President may not amend decisions issued by courts in civil law cases (e.g. cases concerning payment of damages), even if such decisions are part of a criminal judgement ${ }^{25}$.

In the context of the Fiscal Criminal Code, there is the principle of simultaneous expunction of all convictions. If a perpetrator was convicted of two or more nonconcurrent criminal offences or if a convicted person committed a criminal offence after the commencement but before the end of the period of expunction, it is only possible that all convictions are expunged (Art. 20(2) of the Fiscal Criminal Code in conjunction with Art. 108 of the Criminal Code).

Pursuant to Art. 20(2) of the Fiscal Criminal Code, fiscal criminal offences committed by soldiers are expunged pursuant to, accordingly, Art. 106, Art. 107 and Art. 108 of the Criminal Code, as well as Art. 336 of the Criminal Code. Art. 336 of the Criminal Code states that: "1. The court may suspend the enforcement of an imprisonment sentence of less than 6 months until a soldier completes his obligatory service with the military. 2. The court may order that a suspended penalty is enforced if, in the period of suspension, a convicted person blatantly violates the legal order or the rules of military discipline. 3. The court may, after hearing an opinion of a unit commander, release a person from serving an imprisonment sentence of less than 6 months if the suspension period lasted at least 6 months and the soldier in question has demonstrated exemplary conduct with respect to his duties or has shown bravery. 4.

\footnotetext{
19 Constitution of the Republic of Poland of 2 April 1997, Official Journal "Dziennik Ustaw" No. 78 item 483 , as amended.

20 P. Winczorek, Komentarz do Konstytucji Rzeczypospolitej Polskiej, Warszawa 2008, p. 294; K. Kozłowski [in:] M. Safjan (ed.), L. Bosek (ed.), Konstytucja RP. Tom II. Komentarz do art. 87-243, Warszawa 2016, p. 683; B. Banaszak, Konstytucja Rzeczypospolitej Polskiej. Komentarz, Warszawa 2012, p. 776; W. Skrzydło, Konstytucja Rzeczypospolitej Polskiej. Komentarz, Warszawa 2013, p. 184.

${ }^{21}$ L. Gardocki, op. cit., p. 212; K. Kozłowski [in:] M. Safjan (ed.), L. Bosek (ed.), op. cit., p. 683.

22 B. Banaszak, op. cit., p. 768; B. J. Stefańska [in:] R. A. Stefański (ed.), Kodeks karny. Komentarz, Warszawa 2015, p. 662; L. Gardocki, op. cit., p. 212.

${ }^{23}$ K. Kozłowski [in:] M. Safjan (ed.), L. Bosek (ed.), op. cit., p. 685; L. Gardocki, op. cit., p. 212; R. A. Stefański, Ułaskawienie w nowych uregulowaniach, „Prokuratura i Prawo” 1997, no. 1, p. 30.

24 L. Gardocki, op. cit., p. 212; B. Banaszak, op. cit., p. 769.

${ }^{25}$ L. Gardocki, op. cit., p. 212; B. Banaszak, op. cit., p. 768.
} 
The court may release a person from serving the sentence mentioned in Section 3 even if the period of suspension lasted less than indicated above, provided there are particularly important reasons. 5. A release from penalty under Sections 3 or 4 causes expunction of conviction by operation of law; if the penalty of fine or another punitive measure was imposed, expunction of conviction may be granted before such penalty or measure are enforced. 6. The provisions in Sections 1-5 above are applied accordingly to persons called for regular military service".

An analysis of the above-quoted provision from the military part of the Criminal Code reveals that an amendment is needed. Art. 336(5) of the Criminal Code covers only a fine and a punitive measure. In the original wording of the Criminal Code, this was correct. However, in 2015 the general part of the Criminal Code was amended and a new category of measures was introduced that are distinct from punitive measures. The institutions of forfeiture and compensatory measures were added. The new category included forfeiture, the obligation to repair damage and to compensate for harm caused as well as exemplary damages. Before, these were classified as punitive measures. When the amendments to the general part of the Criminal Code were introduced, the military part of the Code was left unchanged. Thus, in the present state of the law, release from a penalty entails expunction of a conviction even if forfeiture or a compensatory measure imposed on a convict have not been enforced yet ${ }^{26}$. With a view to future law, an addition of forfeiture and a compensatory measure to Art. 336(5) of the Criminal Code should be postulated. ${ }^{27}$ An amendment to this provision is necessary also for other reasons. As it is now, the provision refers only to enforcement of a penalty or punitive measure. The literature mentions, however, that this also implies in other events which have similar effects to enforcement of a penalty or punitive measure, i.e. absolution of a conviction or expiration of the deadline for enforcement ${ }^{28}$. This author believes that it should be assumed that de lege lata, considering the clear wording of this provision, it only covers enforcement of a penalty or a punitive measure. Such regulation is not, however, founded, since the provisions of the general part of the Criminal Code concerning expunction of a conviction (Art. 107) always address - in addition to enforcement - absolution and expiration of the deadline for enforcement. With a view to future law, Art. 336(5) of the Criminal Code should be extended to include absolution of conviction and expiration of the deadline for enforcement.

Expunction of a conviction for fiscal criminal offences also happens in the case of full decriminalisation. Art. 2(6) of the Fiscal Criminal Code provides as follows: "If pursuant to a new statute, a forbidden act subject to a ruling is no longer forbidden under penalty, the relevant conviction shall be expunged by operation of law and the penalty

\footnotetext{
${ }^{26}$ So also J. Majewski [in:] A. Zoll (ed.), Kodeks karny. Tom III. Komentarz do art. 278-363, Warszawa 2016, p. 980.

27 So also J. Majewski [in:] A. Zoll (ed.), op. cit., p. 980.

${ }^{28}$ So J. Majewski [in:] A. Zoll (ed.), op. cit., p. 979. Similarly D. Szeleszczuk [in:] A. Grześkowiak (ed.), K. Wiak (ed.), Kodeks karny. Komentarz, Warszawa 2015, p. 1421; W. Marcinkowski, Kodeks karny. Część wojskowa. Komentarz, Warszawa 2011, p. 188.
} 
shall be deemed to have never occurred". Expunction of a conviction is effected ipso iure upon enactment of a statute that decriminalises a certain type of behaviour. It should be emphasised that what is meant here is full decriminalisation. There is an agreement between authors that the provision in question does not apply to partial decriminalisation where a fiscal criminal offence is re-classified as a fiscal misdemeanour ${ }^{29}$. This position is well-founded. It is, however, disputable whether the examined provision also covers fiscal decriminalisation ${ }^{30}$. The so-called fiscal decriminalisation occurs when an act constituting a fiscal criminal offence or fiscal misdemeanour is no longer regarded as an act forbidden under penalty pursuant to the Fiscal Criminal Code. It is, however, possible for such an act to be qualified as a common criminal offence or misdemeanour after the legislator decides to transplant it from the Fiscal Criminal Code to the Criminal Code or Misdemeanours Code or another act or statute containing criminal provisions. This gives rise to a question whether Art. 2(6) of the Fiscal Criminal Code refers to fiscal decriminalisation or general decriminalisation, i.e. decriminalisation in light of the whole criminal law system. The author believes it is the latter. If Art. 2(6) of the Fiscal Criminal Code was meant to cover fiscal decriminalisation only, the legislator would have formulated the provision differently. They could have stipulated that "a forbidden act subject to a ruling is no longer forbidden under penalty as a fiscal criminal offence or fiscal misdemeanour" or that "a forbidden act subject to a ruling is no longer forbidden under penalty envisaged in the Code" 31 . Ergo, there is no expunction of conviction for a fiscal criminal offence if, according to a new statute, a forbidden act subject to a ruling is no longer forbidden under penalty pursuant to the Fiscal Criminal Code but it is forbidden under penalty pursuant to the Criminal Code or Misdemeanours Code or another statute or act defining acts forbidden under penalty.

\section{Expunction of conviction for fiscal misdemeanours}

A fiscal misdemeanour is defined in Art. 53(3) of the Fiscal Criminal Code. Pursuant to this provision, "a fiscal misdemeanour is an act forbidden by the Code under penalty of fine of a certain amount if the amount of a public law liability that has been unlawfully reduced or exposed to unlawful reduction or if the value of the object of the act is not greater than five times the minimum wage as at the moment the act was committed. A different forbidden act can also constitute a fiscal misdemeanour if the Code provides so".

Art. 47(1) of the Fiscal Criminal Code provides that fiscal misdemeanours are punished with a fine of a certain amount. The rules for imposing the penalty of fine are mentioned in Art. 48 of the Fiscal Criminal Code as follows: "1. The penalty of fine can

\footnotetext{
${ }^{29}$ So also L. Wilk [in:] L. Wilk, J. Zagrodnik, op. cit., p. 27.

30 See e.g.: L. Wilk [in:] L. Wilk, J. Zagrodnik, op. cit., pp. 26-27; T. Grzegorczyk, Kodeks karny skarbowy. Komentarz, Warszawa 2006, p. 111.

31 So also L. Wilk [in:] L. Wilk, J. Zagrodnik, op. cit., p. 27.
} 
amount to one-tenth of the minimum wage to twenty times the minimum wage, unless the Code provides otherwise. 2. A fixed penalty notice can be issued to impose a penalty of fine where the amount of the fine is not higher than twice the minimum wage. 3. A court order can be issued to impose a penalty of fine where the amount of the fine is not higher than ten times the minimum wage. 4 . When imposing a penalty of fine or issuing a fixed penalty notice for this purpose, a perpetrator's financial standing, familial situation, income and ability to earn are taken into account".

Pursuant to Art. 47(2) of the Fiscal Criminal Code, punitive measures used in fiscal misdemeanours include: 1) voluntary submission to liability; 2) forfeiture of objects; 3) collection of a monetary equivalent to forfeiture of objects. According to Art. 47(4) of the Fiscal Criminal Code, forfeiture of objects mentioned in Section 2(2) can be decreed as a protective measure.

Expunction of conviction for fiscal misdemeanours is regulated under Art. 52 of the Fiscal Criminal Code. Pursuant to Art. 52(1) of the Fiscal Criminal Code, an imposed penalty or punitive measure defined in Art. 47(2)(2) and (3) is expunged 2 years after the enforcement of the penalty, absolution or expiration of the deadline for enforcement, unless the Code provides otherwise. The above provision stipulates that - similar to the case of fiscal criminal offences - expunction may not be applied to the punitive measure mentioned in Art. 47(2)(1), i.e. to voluntary submission to liability.

Expunction of conviction is effected by operation of law. In the case of fiscal misdemeanours, the Fiscal Criminal Code does not envisage an earlier expunction of conviction following a petition. This situation does not raise any objections because the period of expunction of conviction is short. Determination of a period after which a convict could file petition for an earlier expunction (e.g. 1 year after enforcement, absolution or expiration of the deadline for enforcement) would be pointless, because it is very likely that proceedings concerning the review of such a petition would not end before the current 2-year period. Moreover, a judgement of conviction issued with respect to a fiscal misdemeanour does not have such a great social significance as a judgement of conviction issued in relation to a fiscal criminal offence. The former does not result in such severe stigmatisation of a convict and does not make it impossible or even difficult - for them to function within society. It should also be noted that information concerning persons convicted of fiscal misdemeanours is not registered in the National Criminal Register (Art. 1(2) of the National Criminal Register Act). Criminal record check certificates issued on the basis of the data in the National Criminal Register, so often required by prospective employers, do not include information that a person was convicted of a fiscal misdemeanour.

In the case of a penalty or punitive measure waiver, the conviction of a fiscal misdemeanour is expunged after a year from passing of the final judgement (Art. 52(2) of the Fiscal Criminal Code). Art. 52(3) of the Fiscal Criminal Code provides as follows: If, after the commencement but before the end of the period defined in Section 
1, a convicted person again committed a fiscal criminal offence, fiscal misdemeanour, criminal offence or misdemeanour for which a penalty or punitive measure specified in Art. 22(2)(2)-(7) and (8) and Art. 47(2)(2) and (3) were imposed, it is only possible that all convictions are expunged. Thus, when it comes to expunction, fiscal misdemeanours are governed by the same principle as fiscal criminal offences - the principle of simultaneous expunction of all convictions. As has been rightfully emphasised in the literature, simultaneous expunction of all convictions makes possible, e.g. a more accurate evaluation of a perpetrator's conduct and, as a result, a more accurate review of new cases involving the same person ${ }^{32}$. The provision quoted above requires that a new act is committed after the start but before the end of the period of expunction but it does not require that a final and binding judgement convicting of the new act is issued in this period.

Art. 52(4) of the Fiscal Criminal Code stipulates that a penalty of fine imposed by means of a fixed penalty notice is expunged 1 year from the date on which the fine was paid or collected or from the expiration of the deadline for its enforcement. It should be noted that where a penalty of fine is imposed by means of a fixed penalty notice on a person who committed a fiscal misdemeanour, there is no conviction but rather punishment. Proceedings to issue a fixed penalty notice are conducted by a non-court authority and no judgement is passed. In the case of fine imposed by means of a fixed penalty notice, we deal with the issue of expunction of punishment rather than that of expunction of conviction.

The penalty of fine can be imposed for a fiscal misdemeanour as a result of court proceedings or out-of-court proceedings to issue a fixed penalty notice. If the penalty of fine is imposed by a court in a judgement of conviction, the period of expunction is 2 years (Art. 52(1) of the Fiscal Criminal Code). If the penalty of fine is imposed by means of a fixed penalty notice, the period of expunction is 1 year (Art. 52(4) of the Fiscal Criminal Code). In both cases, we deal with the same type of penalty. This solution raises objections among some representatives of the Polish doctrine ${ }^{33}$. If a person who committed a fiscal misdemeanour refuses to accept a fixed penalty notice and is subsequently convicted of the same misdemeanour by a court and the penalty of fine is imposed, the period of expunction will be twice as long as it would be if they had accepted the fixed penalty notice in the first place. Thus, in the present state of the law, perpetrators who agree to accept a fixed penalty notice are, in a way, "rewarded". As a result, it is possible to avoid costly court proceedings, which is beneficial from the procedural economics perspective. The differentiation of the periods of expunction is, thus, connected to the type of proceedings as part of which the penalty of fine is sought ${ }^{34}$. The statutory solution in the form of a shortened period of expunction in the case of fine imposed by means of a fixed penalty notice is adequate.

\footnotetext{
${ }^{32}$ A. Piaseczny [in:] A. Wielgolewska, A. Piaseczny, Kodeks karny skarbowy. Komentarz, Warszawa 2012, p. 149.

33 See L. Wilk [in:] L. Wilk, J. Zagrodnik, op. cit., p. 214.

${ }^{34}$ Similarly L. Wilk [in:] L. Wilk, J. Zagrodnik, op. cit., p. 214.
} 
The provision of Art. 52(4) of the Fiscal Criminal Code provides that the period of expunction should be counted "from the date on which the fine was paid or collected or from the expiration of the deadline for its enforcement". On the other hand, Art. 52(1) of the Fiscal Criminal Code mentions that the period of expunction should be counted from the moment of "enforcement of the penalty, absolution or expiration of the deadline for enforcement". The expression "from the date on which the fine was paid or collected" is an elaboration of the expression "from the date on which the fine was enforced" since the enforcement of a fine is effected through its payment by the obliged person or through its collection by a competent authority. In accordance with administrative enforcement regulations, a fine is collected when an obliged person fails to pay it within an indicated period. The above provision of Art. 52(4) of the Fiscal Criminal Code can then be deemed as correct. However, Art. 52(4) of the Fiscal Criminal Code omits the question of "absolution", which is more doubtful and gives rise to the question of whether this is a suitable solution.

To answer the above question, it must first be established whether it is possible to "absolve" a penalty for a fiscal misdemeanour imposed by means of a fixed penalty notice. It should be noted that the liability for misdemeanours and fiscal misdemeanours is a repressive liability. The penalties imposed for misdemeanours and fiscal misdemeanours are repressive in nature and differ from penalties imposed for criminal offences and fiscal criminal offences by the degree of severity. Absolution is legally possible under an amnesty act or through a pardon. In the literature on constitutional law, it is claimed that absolution may apply to all legally binding penalties, including penalties imposed as a result of misdemeanour proceedings ${ }^{35}$. As concerns the misdemeanours defined in the Misdemeanours Code, it is commonly accepted that absolution may be granted on the basis of an amnesty or a pardon ${ }^{36}$. The application of a pardon to misdemeanours could be supported by Art. 14(1)(2) of the National Criminal Register Act pursuant to which personal data of, e.g. persons who were convicted of misdemeanours and sentenced to detention is removed from the Register if the conviction was expunged by operation of law or after a notice is issued that the conviction is expunged as a result of a pardon or amnesty. Recently, in the literature an opinion has been presented that the right of pardon should also be applied with respect to liability for fiscal misdemeanours ${ }^{37}$. The above opinions are sound and adequate. On the other hand, the application of pardons in proceedings to issue fixed penalty notice is very rarely tackled in the literature on the subject. Most

\footnotetext{
35 B. Banaszak, op. cit., p. 768; P. Winczorek, op. cit., p. 294; K. Kozłowski [in:] M. Safjan (ed.), L. Bosek (ed.), op. cit., p. 685.

36 T. Bojarski [in:] T. Bojarski (ed.), Kodeks wykroczeń. Komentarz, Warszawa 2009, p. 104; M. Leciak [in:] P. Daniluk (ed.), Kodeks wykroczeń. Komentarz, Warszawa 2016, pp. 261-262; W. Radecki [in:] M. Bojarski, W. Radecki, Kodeks wykroczeń. Komentarz, Warszawa 2013, p. 377; T. Grzegorczyk [in:] T. Grzegorczyk (ed.), Kodeks wykroczeń. Komentarz, Warszawa 2013, p. 196; M. Mozgawa [in:] M. Mozgawa (ed.), Kodeks wykroczeń. Komentarz, Warszawa 2009, p. 144; R. A. Stefański, op. cit., pp. 23-24.

37 K. Kaczmarczyk-Kłak, Prawo łaski w Polsce na tle porównawczym. Dawniej i współcześnie, Rzeszów 2013, p. 413.
} 
authors do not address this question expressly. It has been, however, pointed out, that from the technical point of view, there should be no doubt as to whether it is possible to use the right of pardon in relation to persons punished for fiscal misdemeanours as part of such a procedure ${ }^{38}$. The author of this article agrees with this opinion. For the act of pardon, the type of penalty, rather than the procedure leading to its imposition, is of key importance. The penalty of fine imposed by means of a fixed penalty notice is a repressive penalty.

Considering the above, it must be concluded that in the present state of the law, there is a legal gap with respect to expunction of a fine penalty imposed by means of a fixed penalty notice where a perpetrator is absolved of this penalty. With a view to future law, it should be postulated that Art. 52(4) of the Fiscal Criminal Code is extended by the concept of "absolution".

Comparing the periods of expunction of conviction for fiscal misdemeanours to periods of expunction of conviction for fiscal criminal offences, we can see that the regulations are not consistent. Pursuant to Art. 20(2) of the Fiscal Criminal Code in conjunction with Art. 107(4a) of the Criminal Code, the penalty of fine imposed in relation to a fiscal criminal offence is expunged 1 year after the enforcement of the penalty, absolution or expiration of the deadline for enforcement. On the other hand, the penalty of fine imposed in relation to a fiscal misdemeanour, i.e. an act causing much less social harm, is expunged 2 years after the enforcement of the penalty, absolution or expiration of the deadline for enforcement (Art. 52(1) of the Fiscal Criminal Code). This is an unreasonable solution ${ }^{39}$. The penalty of fine imposed in relation to a fiscal misdemeanour should also be expunged 1 year after the enforcement of the penalty, absolution or expiration of the deadline for enforcement. The proposed amendment to Art. 52(1) of the Fiscal Criminal Code implies the necessity to shorten the period of expunction envisaged in Art. 52(4) of the Fiscal Criminal Code. It also seems wellfounded to shorten the period mentioned in Art. 52(2) of the Fiscal Criminal Code concerning expunction in the case of a penalty or punitive measure waiver. This author believes that a 6-month period would be adequate in the case of both of the above provisions.

Expunction of a conviction for fiscal misdemeanours also happens in the case of full decriminalisation. Art. 2(6) of the Fiscal Criminal Code ("If pursuant to a new statute, a forbidden act subject to a ruling is no longer forbidden under penalty, the relevant conviction shall be expunged by operation of law and the penalty shall be deemed to have never occurred") also applies to fiscal misdemeanours. Similar to the case of fiscal criminal offences, it should be assumed that the provision refers to general decriminalisation. Thus, the conviction of a fiscal misdemeanour is not expunged if,

\footnotetext{
38 So P. Rogoziński, Instytucja ułaskawienia w prawie polskim, Warszawa 2009, p. 234.

39 This problem was already noticed in the doctrine - see S. Kowalski, O. Włodkowski, „Odpowiednie” stosowanie znowelizowanych przepisów Części ogólnej Kodeksu karnego na gruncie Kodeksu karnego skarbowego, „Monitor Prawniczy" 2016, no. 6, pp. 305-306.
} 
according to a new statute, a forbidden act subject to a ruling is no longer forbidden under penalty defined in the Fiscal Criminal Code but it is still forbidden under penalty defined in the Misdemeanours Code or another statute or act regulating a sphere of life and defining misdemeanours involving violation of orders or restrictions applicable to that sphere.

Art. 2(6) of the Fiscal Criminal Code is clear in that it addresses a "forbidden act subject to a ruling", i.e. an act with respect to which a judgement was passed. A ruling may take the form of a judgement or a decision (Art. 117(1) of the Fiscal Criminal Code, Art. 113(1) of the Fiscal Criminal Code, in conjunction with Art. 92 of the Code of Criminal Procedure). Imposing a fine by means of a fixed penalty notice does not constitute a ruling (Art. 117(2) of the Fiscal Criminal Code). Thus, a forbidden act covered by a fixed penalty notice (an act punished by means of a fixed penalty notice) is not a forbidden act subject to a ruling. Consequently, de lege lata, if an act for which the penalty of fine was imposed on the perpetrator by means of a fixed penalty notice issued by a competent authority no longer constitutes an act forbidden under penalty, such punishment is not deemed as if it has never occurred despite decriminalisation. Such punishment will be expunged only after the end of the period envisaged in Art. 52(4) of the Fiscal Criminal Code. This is not a reasonable solution. It might be then concluded that it is necessary to amend Art. 2(6) of the Fiscal Criminal Code by replacing the expression "ruling" with the expression "ruling or a fixed penalty notice".

\section{Final conclusions}

In the present state of the law, the quality of the provisions of the Polish Fiscal Criminal Code applicable to the expunction of conviction for fiscal criminal offences should be assessed as satisfactory. The above analysis of the provisions of the Fiscal Criminal Code applicable to the expunction of conviction for fiscal misdemeanours leads to the conclusion that the provisions in question should be amended by taking into account the proposed de lege ferenda postulates.

\section{Acknowledgements}

The research was co-financed with the funds earmarked for financing of the statutory activities of the Faculty of Law, Administration and International Relations of Andrzej Frycz Modrzewski Krakow University (research task No.: WPAiSM/DS/14/2017-KON).

\section{REFERENCES}

Banasik K., Istota zatarcia skazania, „Wojskowy Przegląd Prawniczy” 2017, no. 2.

Banasik K., Ustawowy wymóg niekaralności [in:] K. Banasik (ed.), A. Kargol (ed.), M. Lubelski (ed.), E. Plebanek (ed.), A. Strzelec (ed.), W poszukiwaniu prawdy. Rozważania o prawie, historii $i$ sprawiedliwości, Kraków 2018. 
Banaszak B., Konstytucja Rzeczypospolitej Polskiej. Komentarz, Warszawa 2012.

Błaszczyk M. [in:] M. Błaszczyk, M. Zbrojewska, Kodeks karny skarbowy, Warszawa 2011.

Błaszczyk M. [in:] M. Królikowski (ed.), R. Zawłocki (ed.), Kodeks karny. Część ogólna. Tom II. Komentarz do art. 32-116, Warszawa 2015.

Bogdan G. [in:] A. Zoll (ed.), Kodeks karny. Część ogólna. Komentarz, t. l: Komentarz do art. 1-116 k.k., Warszawa 2007.

Bojarski T. [in:] T. Bojarski (ed.), Kodeks wykroczeń. Komentarz, Warszawa 2009.

Constitution of the Republic of Poland of 2 April 1997, Official Journal "Dziennik Ustaw" No. 78 item 483, as amended.

Gardocki L., Prawo karne, Warszawa 2013.

Grzegorczyk T. [in:] T. Grzegorczyk (ed.), Kodeks wykroczeń. Komentarz, Warszawa 2013.

Grzegorczyk T., Kodeks karny skarbowy. Komentarz, Warszawa 2006.

Grześkowiak A. [in:] A. Grześkowiak (ed.), K. Wiak (ed.), Kodeks karny. Komentarz, Warszawa 2015.

Kaczmarczyk-Kłak K., Prawo łaski w Polsce na tle porównawczym. Dawniej i współcześnie, Rzeszów 2013.

Kłączyńska N. [in:] J. Giezek (ed.), Kodeks karny. Część ogólna. Komentarz, Warszawa 2012.

Konarska-Wrzosek V. [in:] V. Konarska-Wrzosek, T. Oczkowski, J. Skorupka, Prawo i postępowanie karne skarbowe, Warszawa 2013.

Kowalski S., Włodkowski O., „Odpowiednie” stosowanie znowelizowanych przepisów Części ogólnej Kodeksu karnego na gruncie Kodeksu karnego skarbowego, „Monitor Prawniczy” 2016, no. 6.

Kozłowski K. [in:] M. Safjan (ed.), L. Bosek (ed.), Konstytucja RP. Tom II. Komentarz do art. 87-243, Warszawa 2016.

Leciak M. [in:] P. Daniluk (ed.), Kodeks wykroczeń. Komentarz, Warszawa 2016.

Łabuda G. [in:] P. Kardas, G. Łabuda, T. Razowski, Kodeks karny skarbowy. Komentarz, Warszawa 2017.

Majewski J. [in:] A. Zoll (ed.), Kodeks karny. Tom III. Komentarz do art. 278-363, Warszawa 2016.

Marcinkowski W., Kodeks karny. Część wojskowa. Komentarz, Warszawa 2011.

Marek A., Kodeks karny. Komentarz, Warszawa 2010.

Marek A., Prawo karne, Warszawa 2011.

Mozgawa M. [in:] M. Mozgawa (ed.), Kodeks wykroczeń. Komentarz, Warszawa 2009.

Piaseczny A. [in:] A. Wielgolewska, A. Piaseczny, Kodeks karny skarbowy. Komentarz, Warszawa 2012.

Prusak F., Kodeks karny skarbowy. Komentarz. Tom I. Komentarz do art. 1-53 k.k.s., Kraków 2006.

Radecki W. [in:] M. Bojarski, W. Radecki, Kodeks wykroczeń. Komentarz, Warszawa 2013.

Rogoziński P., Instytucja ułaskawienia w prawie polskim, Warszawa 2009.

Ruling of the Supreme Court of 10 November 2010, IV KK 326/10, „Prokuratura i Prawo” „Orzecznictwo" 2011, no. 3, item 8.

Ruling of the Supreme Court of 18 June 2009, IV KK 164/09, LEX no. 512114.

Ruling of the Supreme Court of 29 August 2013, IV KK 168/13, http://www.sn.pl/sites/orzecznictwo/orzeczenia3/iv\%20kk\%20168-13.pdf, accessed: 25.02.2017. 
Ruling of the Supreme Court of 9 December 2009, V KK 303/09, LEX no. 553740.

Skrzydło W., Konstytucja Rzeczypospolitej Polskiej. Komentarz, Warszawa 2013.

Statute of 10 September 1999 - The Fiscal Criminal Code, Official Journal "Dziennik Ustaw" No. 83 item 930, as amended.

Statute of 24 May 2000 on the National Criminal Register, Official Journal "Dziennik Ustaw" No. 50 item 580 , as amended.

Statute of 6 June 1997 - The Criminal Code, Official Journal "Dziennik Ustaw" No. 88 item 553, as amended.

Stefańska B. J. [in:] R. A. Stefański (ed.), Kodeks karny. Komentarz, Warszawa 2015.

Stefański R. A., Ułaskawienie w nowych uregulowaniach, „Prokuratura i Prawo” 1997, no. 1.

Szeleszczuk D. [in:] A. Grześkowiak (ed.), K. Wiak (ed.), Kodeks karny. Komentarz, Warszawa 2015.

Wielgolewska A. [in:] A. Wielgolewska, A. Piaseczny, Kodeks karny skarbowy. Komentarz, Warszawa 2012.

Wilk L. [in:] L. Wilk, J. Zagrodnik, Kodeks karny skarbowy. Komentarz, Warszawa 2016.

Winczorek P., Komentarz do Konstytucji Rzeczypospolitej Polskiej, Warszawa 2008.

Wróbel W., Zoll A., Polskie prawo karne. Cześć ogólna, Kraków 2013. 